\title{
EFFECT OF PREPARING CONDITIONS ON PROPERTIES OF GELATIN FILM FROM HORSE MACKEREL SCALE
}

\author{
Le Thi Minh Thuy, Hiroki Maki, Emiko Okazaki, Kazufumi Osako* \\ Food Processing Laboratory, Tokyo University of Marine Science and Technology, \\ Minato-ku, Tokyo, 108-8477, Japan \\ *e-mail: osako@kaiyodai.ac.jp
}

\begin{abstract}
In this study, the effect of preparing conditions, such as protein concentrations and glycerol concentrations of film forming solution (FFS) on properties of gelatin film from horse mackerel scale were investigated. Properties of edible film from gelatin was extracted at $70^{\circ} \mathrm{C}$ for $1 \mathrm{~h}$ at various protein concentrations $(1,2$, and $3 \%)$ in film-forming solution (FFS) were examined.. Films from FFS containing higher protein content showed the higher TS and EAB. WVP of film increased with increasing protein concentration of FFS. The study about the effect of glycerol in FFS on the film property showed that addition of glycerol as a plasticizer into FFS at the concentrations of $0,10,15,20$ and $25 \%$ of protein lead to the decline of TS of gelatin film, while both EAB and WVP of film increased. The SDS-PAGE patterns showed that all gelatin films consisted of two different $\alpha$ chains, $\alpha 1$ and $\alpha 2$, as well as a $\beta$ component and no differences in protein patterns among the protein concentrations and glycerol concentrations of FFS.
\end{abstract}

Key words: gelatin, films, horse mackerel, scales.

\section{INTRODUCTION}

Gelatin, one of the most popular biopolymers, is widely used in food field because it has unique functional and technological properties. Gelatin is extracted from mammalian resource and marine resource. One of these important applications of fish gelatin was film-forming ability. Fish gelatin film used as covering foodstuffs has ability to protect food against drying, light and oxygen (Gómez-Guillén et al. 2008).

Horse mackerel (Trachurus japonicus) is one of the most important fish species in Japan, and used as a raw materials of frozen surimi (Simizu 1987, Yamanaka and Tanaka 2007). However, during fish processing, a large amount of byproducts, such as skin, scales and bone, which accounts for $50-70 \%$ of fish weight, are discarded and underutilized (Kittiphattanabawon et al. 2005). Utilization of marine waste, including scales, is necessary from the viewpoints of both environmental conservation and the development of new industries.

\section{MATERIAL AND METHODS}

\section{Preparation of gelatin films}

Gelatin powder extracted at $70^{\circ} \mathrm{C}$ for $1 \mathrm{~h}$ was dissolved in distilled water at $60^{\circ} \mathrm{C}$ for 30 $\min$ to obtain the FFS with protein concentration of 1,2 , and $3 \%(w / v)$ determined by Lowry's method. Glycerol as a plasticizer was added into FFS at the concentration of $20 \%(w / w)$ of protein. The air bubbles in FFS were removed by a hybrid mixer (HM - 500; Keyence Co., Tokyo, Japan). The prepared FFS $(4 \mathrm{~g})$ was cast onto a rimmed silicone plate $(50 \times 50 \mathrm{~mm})$ 
and dried at a ventilated oven (EYELA, KCL - 2000A, Tokyo Rikakikai Co., Ltd., Japan) at 25 $\pm 0.5^{\circ} \mathrm{C}$ and $50 \pm 5 \%$ relative humidity $(\mathrm{RH})$ for $24 \mathrm{~h}$. To study the effect of glycerol concentration on gelatin film from a $2 \%$ protein FFS, glycerol at the concentration of $0,10,15$, 20 , and $25 \%(\mathrm{w} / \mathrm{w})$ of protein was added. The prepared FFS was cast and dried to form the film as previously described.

\section{Mechanical properties}

TS and EAB of film samples were determined according to the ASTM standard method D 882 - 97 by using a Tensipresser (TTP - 50BX II, Taketomo Electric Inc., Tokyo, Japan).

\section{Water vapour permeability}

WVP of film was measured according to the ASTM standard method as reported by Gontard et al. 2007. Films were sealed onto a glass cup containing silica gel (O\% RH) with silicon vacuum grease and plastic band to hold the film in place. The cups were then placed in a desiccator with saturated water $(100 \% \mathrm{RH})$ at $30^{\circ} \mathrm{C}$. The cups were weighed at $1 \mathrm{~h}$ intervals over $9 \mathrm{~h}$ periods.

\section{Electrophoretic analysis}

SDS - PAGE of gelatin films from horse mackerel scale was analyzed according to the method of Limpisophon et al. 2009 with slight modifications.

\section{RESULT AND DISCUSSION}

\section{Effect of protein concentrations on gelatin film}

\subsection{Mechanical properties}

TS and EAB of gelatin film increased with increasing protein concentration of FFS. (Data are not shown.)

\subsection{Water vapor permeability}

WVP of gelatin film increased from 0.4 to $1.4\left(\times 10^{-10} \mathrm{gm}^{-1} \mathrm{~Pa}^{-1} \mathrm{~s}^{-1}\right)$ with increasing FFS protein concentration.

\subsection{SDS-PAGE}

The SDS-PAGE pattern showed that all gelatin film at various protein concentrations consisted of two different $\alpha$ chains ( $\alpha 1$ and $\alpha 2$ ) and $\beta$ component. There were no differences in patterns among the glycerol content. (Data are not shown.)

\section{Effect of glycerol concentrations on gelatin film}

\subsection{Mechanical properties}

TS decreased with increasing glycerol concentration from 0 to $25 \%$. On the other hand, $E A B$ of gelatin film from horse mackerel scale increased sharply. (Data are not shown.)

\subsection{Water vapor permeability}

WVP value of gelatin film increased from 0.7 to $1.1\left(\times 10^{-10} \mathrm{gm}^{-1} \mathrm{~Pa}^{-1} \mathrm{~s}^{-1}\right)$ with increasing glycerol concentration.

\subsection{SDS-PAGE}


The SDS-PAGE pattern showed that all gelatin film at all glycerol concentrations consisted of two different $\alpha$ chains $(\alpha 1$ and $\alpha 2)$ and $\beta$ component. There were no differences in patterns among the glycerol content. (Data are not shown.)

\section{CONCLUSION}

Properties of gelatin films from horse markerel scales depend on the preparation conditions. Increasing protein concentrations in FFS led to the increasing TS, EAB and WVP value. $E A B$ and $W V P$ also increased but TS decreased with increasing glycerol concentrations in FFS.

\section{REFERENCES}

ASTM. 1983. In Annual book of ASTM standards.

Gómez-Guillén MC., Pérez-Mateos M, Gómez-Estaca J, López-Caballero E., Giménez B, Montero P. 2008. Fish gelatin: A renewable material for developing active biodegradable films. Trends in Food Science \& Technology, , 1-14.

Gontard N, Guilbert S, Cuq JL. 1992. Edible wheat gluten films: influence of the main process variables on film properties using response surface methodology. Journal of Food Science, 57(1), 190-195.

Kittiphattanabawon P, Benjakul S., Visessaguan W, Nagai T, Tanaka M. 2005. Characterisation of acid soluble collagen from skin and bone of bigeye snapper (Priacanthus tayenus). Food Chemistry, 89, 363-372.

Limpisophon K, Tanaka M., Weng W, Abe S, Osako K. 2009. Characterization of gelatin films prepared from under-utilized blue shark (Prionace glauca) skin. Food Hydrocolloids, 23, 1993-2000.

Lowry OH, Rosebrough NJ, Farr AL., Randall RJ. 1951. Protein measurement with Folin phenol reagent. Journal of Biological Chemistry, 193, 256-275.

Shimizu U. 1987. Neriseihin In Suyama, M., \& Kounosu, S. (eds), Suisanshokuhingaku (pp. 262264). Tokyo: Kouseisha kouseikaku (in Japanese).

Yamanaka H, Tanaka M. 2007. Suisanbutsu no riyou. (2nd ed.) (pp. 18-28). Tokyo: Seizando shoten (in Japanese). 